\title{
INVESTIGATION OF THE IN VITRO REGENERATION OF SOME MEDICAL AND AROMATIC WILD PLANT SPECIES
}

\author{
TUNCER, B. \\ Yuzuncu Yil University, Agricultural Faculty, Department of Horticulture, Van, Turkey \\ e-mail: brctuncer@gmail.com; phone: +90-444-50-65 \\ (Received $28^{\text {th }}$ May 2017; accepted $2^{\text {nd }}$ Aug 2017)
}

\begin{abstract}
Ferula orientalis L., Chaerophyllum macrospermum (Spreng.) Fisch. \& C.A.Mey., and Eremurus spectabilis M.Bieb are among the medically and aromatically important wild plant species. This study was conducted to obtain in vitro shoot regeneration from different plant segments in these three species. For this purpose, different plant segments (rhizome, leaf, or single-node explants) were cultured in Murashige and Skoog medium with the addition of either 2,4-dichlorophenoxyacetic acid (2,4D) $(0.5-2.0 \mathrm{mg} / \mathrm{l})$ or 2,4-D combined with 6-Benzylaminopurine (BAP) $(1.0-2.0 \mathrm{mg} / \mathrm{l})$. For the singlenode explants of Ferula orientalis L., the highest shoot number per explant (3.0 shoots/explant) was obtained in the medium with $0.5 \mathrm{mg} / 1$ 2,4-D $+2.0 \mathrm{mg} / \mathrm{l}$ BAP added. For Chaerophyllum macrospermum (Spreng.) Fisch. \& C.A.Mey., the highest shoot number per explant (2.5 shoots/explant) was obtained in the medium with $1.0 \mathrm{mg} / \mathrm{l}$ 2,4-D + $2.0 \mathrm{mg} / \mathrm{l}$ BAP added. For Eremurus spectabilis M.Bieb., shoot formation was not observed in either of the explant types (leaf or rhizome) in any of the medium combinations. In further studies, the combined applications of $2 \mathrm{mg} / \mathrm{l}$ or above doses of BAP and lower auxin concentrations may be useful for in vitro shoot regeneration in Ferula orientalis L. and Chaerophyllum macrospermum (Spreng.) Fisch. \& C.A.Mey.

Keywords: Ferula orientalis L., Chaerophyllum macrospermum (Spreng.) Fisch. \& C.A.Mey., Eremurus spectabilis M. Bieb., micropropogation
\end{abstract}

\section{Introduction}

Ferula orientalis L. (synonym of Polycyrtus cachroides Schlecht.) is a plant with high adaptability and is frequently grown in Iran, Afghanistan, and in the East Anatolian Region of Turkey (Hakkari and Van). It is locally referred to as heliz or kevk (Kaval, 2011). Ferula orientalis L. is from the Apiaceae family and is a perennial, herbaceous plant that can grow up to $60-100 \mathrm{~cm}$. In addition to its importance as a food source, it has a therapeutic value and can be used as a fodder plant. Young shoots and leaves of the plant, which have a high nutritional value, are boiled and dried after chopping to rid them of their bitter taste. Then, they are added to dishes and Van herbed cheese (Baytop, 1999; Ozturk et al., 2000). In the summer, the shoots and leaves of the plant are cut and left to dry to feed animals in the winter (Baytop, 1999; Cakılcioglu et al., 2007). The plant's sap is obtained by boiling the roots and is used to treat stomachaches, hemorrhoids, intestinal parasites, eczema, fungal infections, and toxic animal bites. Oils derived from the plant have antifungal and antibacterial properties (Tuzlacı and Dogan, 2010).

Chaerophyllum macrospermum (Spreng.) Fisch. \& C.A.Mey. (synonym of Scandix macrospermum Wild. ex Spreng. ) is a perennial, herbaceous plant that grows in high altitudes and humid habitats and is locally referred to as mendi (Kaval, 2011). It is from the Apiaceae family, can grow up to $40-60 \mathrm{~cm}$, and has a thin stem that has a mint-like taste. The plant is used by the locals as a spice and vegetable. In addition to its use in Van herbed cheese and local dishes, it can be pickled, added to soups, and consumed fresh (Ozcelik, 1992). Its use as a food source is more common than Ferula orientalis L. 
Eremurus spectabilis M.Bieb. is a perennial, herbaceous plant from the Eremurus genus of the Liliaceae family. The Iran/Turan region, especially Central Asia, is the center of origin of the species. In Turkey, it is a wild plant that grows on the mountains of the Eastern and Southeastern Anatolia Regions. It is locally known as ciris, wild leek, and yellow lily. Its fresh shoots and leaves are consumed as vegetables. In addition to its use as a food source, it has a therapeutic value and is used as an adhesive in industry. Thanks to its similarity to spinach in terms of cooking style, it can be added to bulgur pilaf or roasted and eaten with eggs, and its leaves and stems can be added to Van herbed cheese (Kaval, 2011). The plant is rich in minerals and is a good source of vitamin $\mathrm{C}$ and antioxidants (Kaplan and Unal, 2011). Its sap, which is obtained by crushing its leaves, is used in the treatment of fungal diseases and eczema (Tuzlaci and Doğan, 2010), and its juice, which is obtained by boiling its roots, is alledged to be treat diabetes and liver disorders (Tuzlacı and Doğan, 2010; Pourfarzad et al., 2014). The roots of the plant have been reported to contain high amounts of mucilage, and Tuzlaci (1985) reported that the plant contained 30\% gum, which is made into an adhesive for use in industry (Gungor, 2002).

In the future, these medically and aromatically important plant species, which are yet to be cultured, will likely be on the verge of extinction as a result of unconsciously collecting the plants from their natural habitats, their irreplaceable use in the making of Van herbed cheese, arbitrary grazing. Therefore, necessary measures should be taken to protect these species. Methods for plant tissue culturing enable the protection of plant biodiversity (Alkowni and Sawalha, 2012). Moreover, thanks to rapid and reliable micropropagation methods, the production of secondary metabolites in medical plants can be increased(Alkowni et al., 2017). Conventional breeding studies on the species from the Apiaceae and Liliaceae families are time consuming and require labor (Tawfik and Noga, 2002; Zare et al., 2010), but tissue culture methods can shorten the time spent on breeding.

In vitro regeneration studies have been carried out on many species from the Apiaceae (Irwani et al., 2010; Zare et al., 2010; Sharma, 2015) and Liliaceae families (Baksha et al., 2005; Skoric et al., 2012; Monemi et al., 2014). It has been reported that the micropropagation of some medical plants, endangered species, wild species, and endemic species was achieved with tissue culture methods (Sahrawat and Chand, 2002; Martin, 2002; Thomas and Jacob, 2004; Paunescu and Holobiuc, 2005). However, these methods should be optimized, and proper protocols must be established for each species. The present study investigated how adding different explant types and different growth hormones to the MS medium (Murashige and Skoog, 1962) medium affected the in vitro propagation of these three medically important wild species. This report is also noteworthy for being the first in vitro regeneration study on these species.

\section{Materials and Methods}

\section{Plant materials, sterilization and explant preparation}

Different plant parts of Eremurus spectabilis M.Bieb., Ferula orientalis L., and Chaerophyllum macrospermum (Spreng.) Fisch. \& C.A.Mey., which were collected from Kırkgeçit Village of Gurpinar County in Van, Turkey, were the material of the study (Fig. 1). For Chaerophyllum macrospermum (Spreng.) Fisch. \& C.A.Mey and Ferula orientalis L., single-node explants were used, and for Eremurus spectabilis M.Bieb, leaf and rhizome explants were used. Rhizomes were rinsed with tap water to remove mud and dirt 
and were kept in tap water overnight. Then, they were rinsed 4-5 times with pure water, placed into a cabinet, and kept in $70 \%$ ethyl alcohol for 10 seconds. Next, a few drops of Tween 20 were added, and the samples were shaken for 15 minutes in $15 \%$ sodium hypochlorite. The Eremurus spectabilis M.Bieb rhizomes were sterilized by shaking the rhizomes with bidistilled water 3-5 times, 6 minutes each time.

The surfaces of the leaf explants and the shoots containing single nodes were sterilized by shaking the samples in $15 \%$ commercial sodium hypochlorite for 15 minutes. Then, they were rinsed with bidistilled water 3 times, 5 minutes for each repetition (Fig. $2 a, 2 b, 2 c, 2 d$ ). Sterilized materials were put on a sterile blotting paper and cleansed of their excess water (Fig. 2e, 2f). Rhizomes were prepared for planting by vertically and horizontally cutting their sides in strips (Fig. $2 g, 2 h, 2 l$ ). To obtain the single-node explants, the nodes that also had shoots half a centimeter above and below were taken and their leaves were removed (Fig. 2i, 2j). To obtain leaf explants, thin strips were taken from the sides and edges of the leaves and prepared for planting (Fig. $2 k$ ). All steps were carried out under aseptic conditions in a laminar flow cabinet.
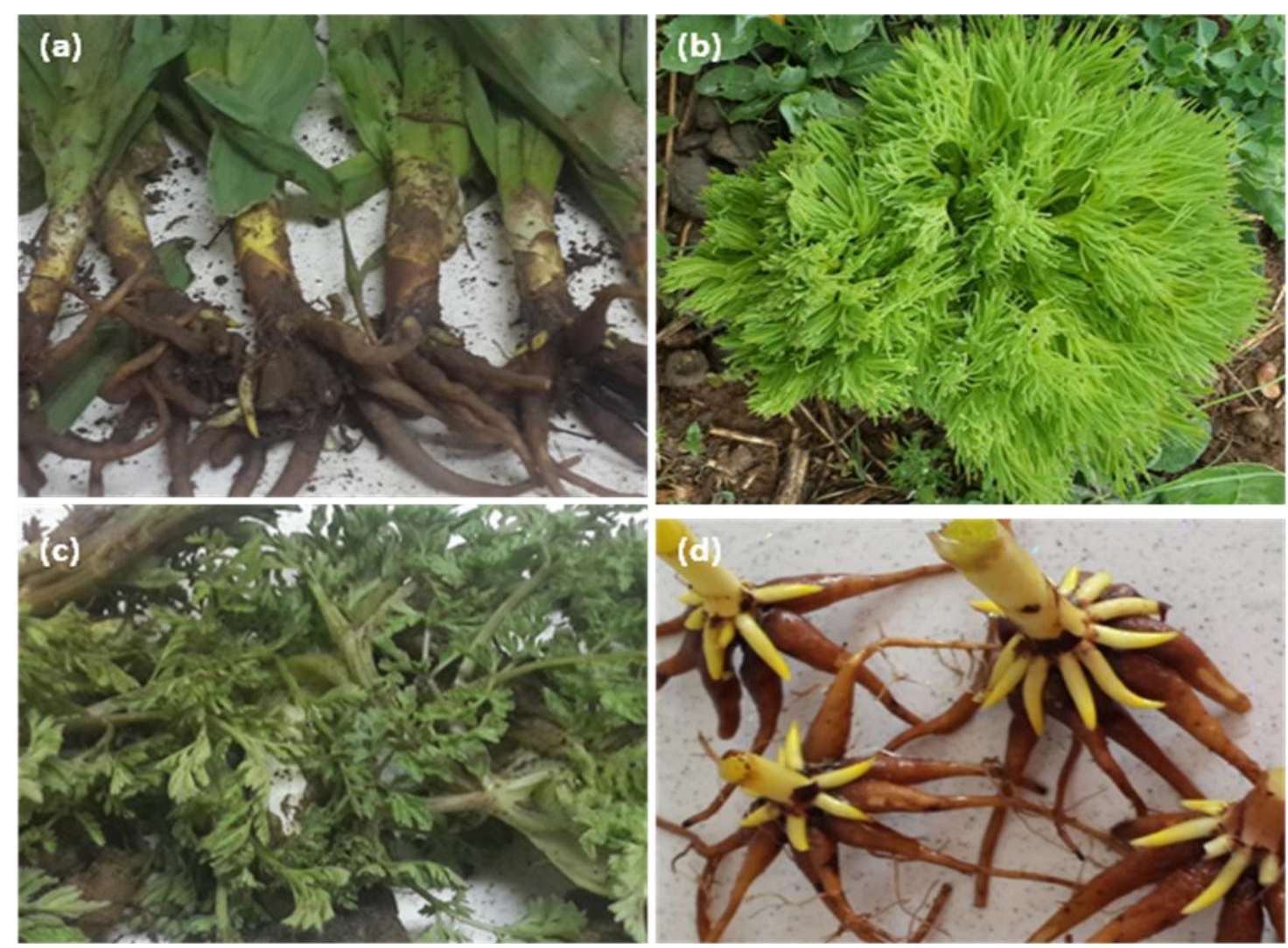

Figure 1. (a) Eremurus spectabilis M.Bieb., (b) Ferula orientalis L., (c) Chaerophyllum macrospermum (Spreng.) Fisch. \& C.A.Mey plants, (d) Eremurus spectabilis M. Bieb. roots and rhizomes.

\section{Medium composition and culture of explants}

The explants were cultured in the MS (Murashige and Skoog, 1962) media containing 9 different combinations of 2,4-dichlorophenoxyacetic acid $(2,4-\mathrm{D})(0.5,1.0$, and $2.0 \mathrm{mg} / \mathrm{l})$ and/or benzylaminopurine (BAP) $(1.0$ and $2.0 \mathrm{mg} / \mathrm{l})$. In addition, $30 \mathrm{~g} / \mathrm{l}$ of 
sucrose and $7 \mathrm{~g} / \mathrm{l}$ of agar was added to the MS medium, and the $\mathrm{pH}$ of the medium was adjusted to 5.8. Each petri dish contained 8 explants and $25 \mathrm{ml}$ of medium. Then, the petri dishes were cultured in a climate room at $25^{\circ} \mathrm{C} \pm 2{ }^{\circ} \mathrm{C}$ with a photoperiodic cycle of 16-hours light/8-hours dark. Each application was planned to be in 4 replicates. The data were evaluated by analyses of variance, and the means were compared by Duncan's multiple range test $(p<0.05)$ using the SPSS statistical package program.
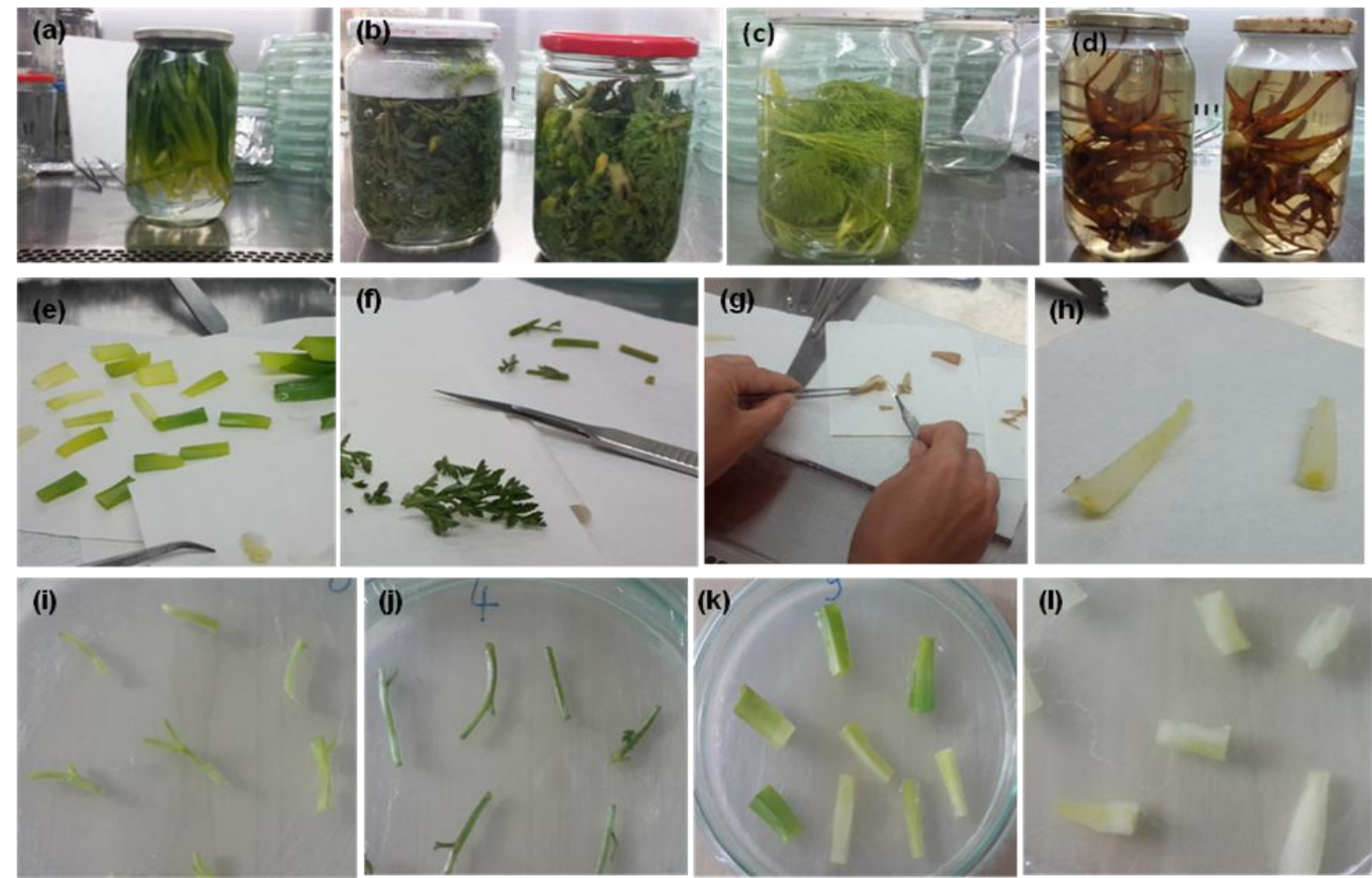

Figure 2. Surface sterilization of the leaves of (a) Eremurus spectabilis M.Bieb, (b) Chaerophyllum macrospermum (Spreng.) Fisch. \& C.A.Mey, and (c) Ferula orientalis L.; (d) sterilization of the rhizomes of Eremurus spectabilis M. Bieb; (e) leaf explants of Eremurus spectabilis M. Bieb; $(f)$ single-node explants of Chaerophyllum macrospermum (Spreng.) Fisch. \& C.A.Mey; $(g-h)$ preparation of the rhizome explants of Eremurus spectabilis M. Bieb; (i) single-node explants of Ferula orientalis $L . ;$ and $(j)$ single-node explants of Chaerophyllum macrospermum (Spreng.) Fisch. \& C.A. Mey, which showed growth in the media 1 week after planting; ( $k$ ) leaf explants; and (l) rhizome explants of Eremurus spectabilis M. Bieb.

\section{Results and Discussion}

Table 1 shows the media composition with the shoot numbers and ratios (\%) obtained from the single-node explants of Ferula orientalis L. and Chaerophyllum macrospermum (Spreng.) Fisch. \& C.A.Mey. For both species, differences among the medium combinations were statistically significant $(p<0.05)$. For Ferula orientalis L., the highest shoot number per explant was obtained in the MS7 medium (3.0 shoot/explant), followed by the MS8 (2.75 shoots/explant) and MS4 (2.25 shoots/explant) media, respectively. For Chaerophyllum macrospermum (Spreng.) Fisch. \& C.A. Mey, the highest shoot number per explant was obtained in the MS8 medium ( 2.50 shoots/explant), followed by the MS7 medium (2.25 shoots/explant). For both species, the least successful media (in terms of shoot numbers and ratios) were the 
media with only auxin added (2,4-D), which were the MS1 (0.5 mg/l 2,4-D), MS2 (1.0 $\mathrm{mg} / \mathrm{l}$ 2,4-D), and MS3 (2.0 mg/l 2,4-D) media (Table 1).

Fig. 3 shows shoot formations in these wild plant species for different explant types and MS medium combinations. It also shows the browning in the explants that occurred in the successive stages of culture.

Table 1. Effect of the combinations of MS medium on in vitro shoot regeneration in the single-node explants of Ferula orientalis L. and Chaerophyllum macrospermum (Spreng.) Fisch. \& C.A.Mey.

\begin{tabular}{|c|c|c|c|c|c|c|c|c|c|c|}
\hline \multirow{3}{*}{ 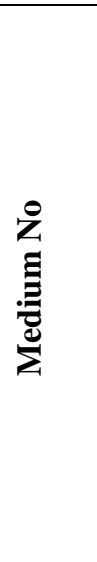 } & & & \multicolumn{4}{|c|}{ Ferula orientalis } & \multicolumn{4}{|c|}{ Chaerophyllum macrospermum } \\
\hline & \multicolumn{2}{|c|}{$\begin{array}{c}\text { Media } \\
\text { composition } \\
(\mathrm{mg} / \mathrm{l})\end{array}$} & \multirow{2}{*}{ 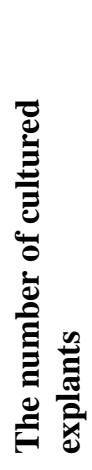 } & \multirow{2}{*}{ 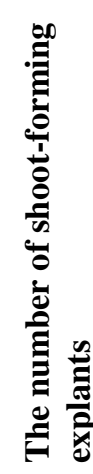 } & \multirow[b]{2}{*}{ 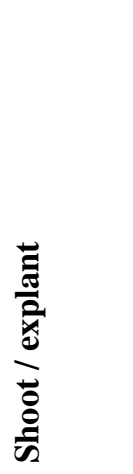 } & \multirow[b]{2}{*}{ 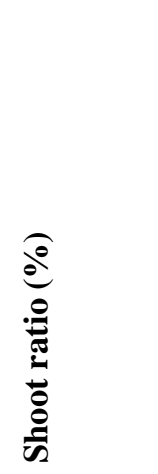 } & \multirow{2}{*}{ 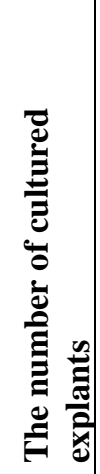 } & \multirow{2}{*}{ 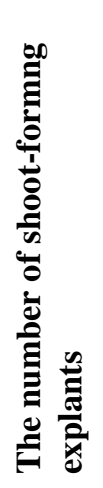 } & \multirow[b]{2}{*}{ 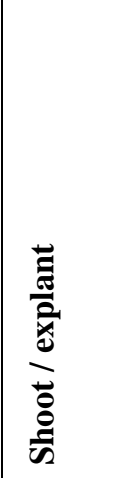 } & \multirow[b]{2}{*}{ 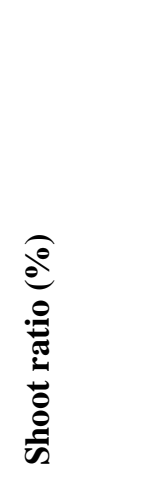 } \\
\hline & $\stackrel{9}{+}$ & $\underset{n}{a}$ & & & & & & & & \\
\hline MS1 & 0.5 & - & 32 & 3 & $0.75 \mathrm{~cd}$ & $9.38 \mathrm{~cd}$ & 32 & 0 & $0.00 \mathrm{~d}$ & $0.00 \mathrm{~d}$ \\
\hline MS2 & 1.0 & - & 32 & 2 & $0.50 \mathrm{~cd}$ & $6.25 \mathrm{~cd}$ & 32 & 0 & $0.00 \mathrm{~d}$ & $0.00 \mathrm{~d}$ \\
\hline MS3 & 2.0 & - & 32 & 0 & $0.00 \mathrm{~d}$ & $0.00 \mathrm{~d}$ & 32 & 0 & $0.00 \mathrm{~d}$ & $0.00 \mathrm{~d}$ \\
\hline MS4 & 0.5 & 1.0 & 32 & 9 & $2.25 \mathrm{ab}$ & $28.13 \mathrm{ab}$ & 32 & 6 & $1.50 \mathrm{bc}$ & $18.75 \mathrm{bc}$ \\
\hline MS5 & 1.0 & 1.0 & 32 & 5 & $1.25 \mathrm{~b}-\mathrm{d}$ & $15.63 \mathrm{~b}-\mathrm{d}$ & 32 & 7 & $1.75 \mathrm{a}-\mathrm{c}$ & $21.88 \mathrm{a}-\mathrm{c}$ \\
\hline MS6 & 2.0 & 1.0 & 32 & 7 & $1.75 \mathrm{a}-\mathrm{c}$ & $21.88 \mathrm{a}-\mathrm{c}$ & 32 & 6 & $1.50 \mathrm{bc}$ & $18.75 \mathrm{bc}$ \\
\hline MS7 & 0.5 & 2.0 & 32 & 11 & $3.00 \mathrm{a}$ & 34.38 a & 32 & 9 & $2.25 \mathrm{ab}$ & $28.13 \mathrm{ab}$ \\
\hline MS8 & 1.0 & 2.0 & 32 & 10 & $2.75 \mathrm{a}$ & $31.25 \mathrm{ab}$ & 32 & 10 & $2.50 \mathrm{a}$ & $31.25 \mathrm{a}$ \\
\hline MS9 & 2.0 & 2.0 & 32 & 5 & $1.25 \mathrm{~b}-\mathrm{d}$ & $15.63 \mathrm{~b}-\mathrm{d}$ & 32 & 4 & $1.00 \mathrm{c}$ & $12.50 \mathrm{c}$ \\
\hline \multicolumn{3}{|c|}{ LSD.05 } & & & 1.16 & 14.71 & & & 0.90 & 11.34 \\
\hline
\end{tabular}

Different small letters in a same column show significant differences among the medium $(p<0.05)$.

The ratios of the growth regulators from the auxin and cytokinin group in the nutrient medium are important for in vitro plant regeneration (Thomas and Maseena, 2006; Irvani et al., 2010). For both species, Table 1 reveals that the medium combinations that obtained relatively higher shoot numbers had low levels of auxin $(2,4-\mathrm{D})$ and high levels of BAP. There have been reports on the positive effect of adding combinations of auxin at low concentrations and growth regulators from the cytokinin group to the nutrient medium on in vitro plant regeneration (Baksha et al., 2005; Skoric et al., 2012; Monemi et al., 2014). These reports agree with the present study.

Monemi et al. (2014) reported that for leek (Allium ampeloprasum) from the Liliaceae family, the best callus formation was obtained in leaf explants in an MS medium with $0.5 \mathrm{mg} / \mathrm{l} 2,4-\mathrm{D}+0.1 \mathrm{mg} / \mathrm{l} \mathrm{BAP}$ and $0.1 \mathrm{mg} / \mathrm{l} 2,4-\mathrm{D}+0.5 \mathrm{mg} / \mathrm{l} \mathrm{kinetin}$ added. In the present study, callus formation was not observed for any of the three species, even in the media with only $2,4-\mathrm{D}$ added $(0.5,1.0$, and $2.0 \mathrm{mg} / \mathrm{l})$. This suggests that using higher doses of auxin to obtain callus formation may prove beneficial in further in vitro regeneration studies on the same species. Zare et al. (2010) reported that, in different explant types (root, hypocotyl, and cotyledon) obtained from sterile 
seedlings of medically important Ferula assa-foetida L., indirect shoot formation was obtained both in only BA-added (1-3 mg/l) and in $0.2-0.5 \mathrm{mg} / \mathrm{l} \mathrm{NAA-added} \mathrm{MS}$ medium combinations. Zare et al. (2010) determined that the highest shoot formation (7.4 shoot/callus) was obtained in the hypocotyl explants in a $1 \mathrm{mg} / \mathrm{l} \mathrm{BA}$-added and 0.2 $\mathrm{mg} / \mathrm{l}$ NAA-added medium. In the present study, direct shoot formation from the explants was obtained in two species (Ferula orientalis L. and Chaerophyllum macrospermum (Spreng). Fisch. \& C.A.Mey.). Irvani et al. (2010) reported that the highest shoot regeneration $(87.3 \%)$ was obtained in the medically important Dorema ammoniacum D. (Apiaceae) from calluses of hypocotyl origin in a MS $+2 \mathrm{mg} / \mathrm{l} \mathrm{BA}+$ $0.2 \mathrm{mg} / \mathrm{l} \mathrm{IBA}$ medium.
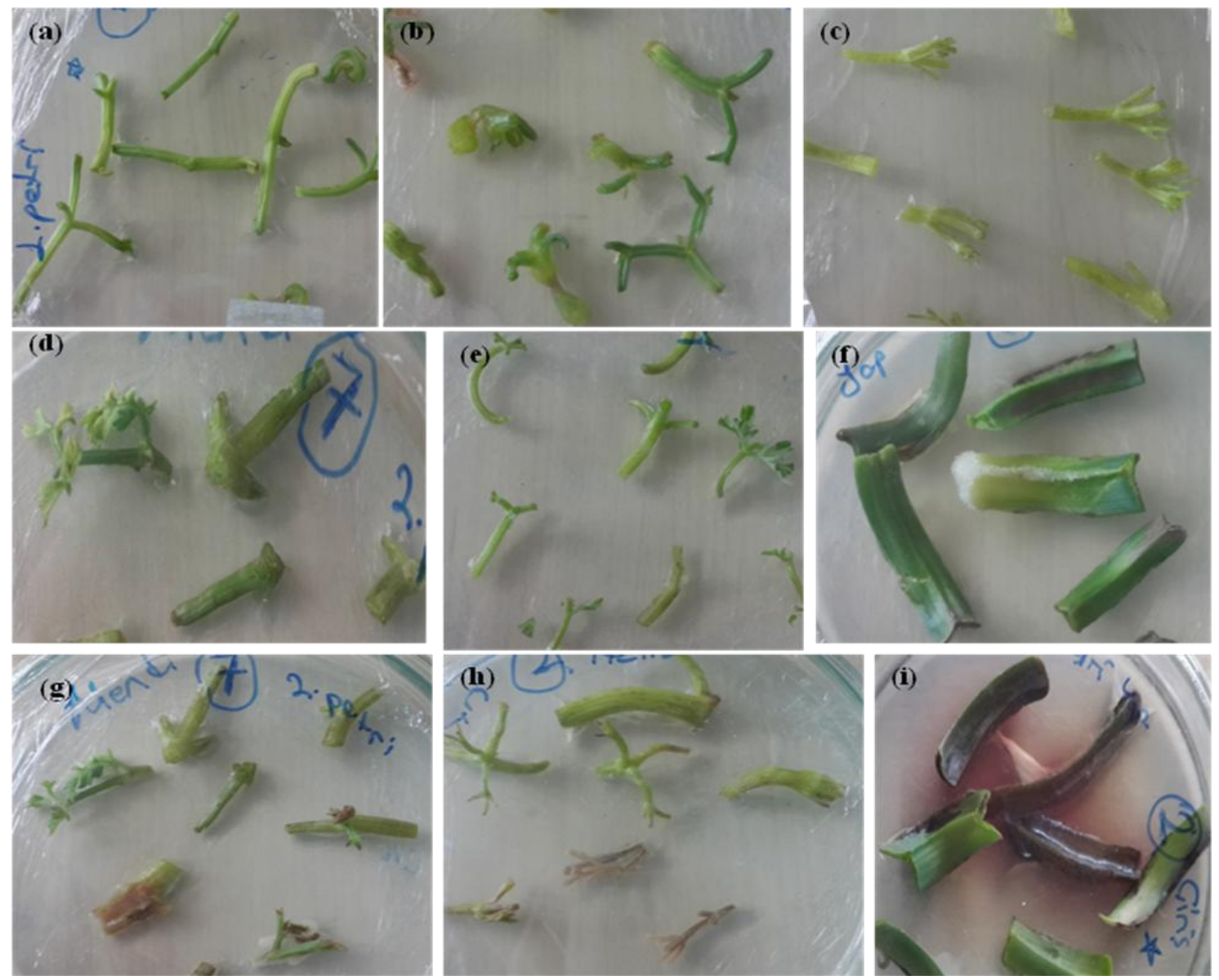

Figure 3. Shoot formation of the single-node explants of Ferula orientalis L. at the (a) $15^{\text {th }}$ day of culturing and at the $(b, c) 25^{\text {th }}$ day of culturing $(0.5 \mathrm{mg} / \mathrm{l} 2,4-D+2.0 \mathrm{mg} / \mathrm{l} \mathrm{BAP})$, shoot formation of the single-node explants of Chaerophyllum macrospermum (Spreng.) Fisch. \& C.A. Mey at the (d) $25^{\text {th }}$ day of culturing $(1.0 \mathrm{mg} / \mathrm{l} 2,4-\mathrm{D}+2.0 \mathrm{mg} / \mathrm{l} \mathrm{BAP})$ and at the (e) $15^{\text {th }}$ day of culturing $(1.0 \mathrm{mg} / \mathrm{l} \mathrm{2,4-D}+1.0 \mathrm{mg} / \mathrm{l} \mathrm{BAP})$, $(\mathrm{f})$ swellings in leaf explants of Eremurus spectabilis M. Bieb at the $15^{\text {th }}$ day of culturing $(0.5 \mathrm{mg} / \mathrm{l} \mathrm{2,4-D}+1.0 \mathrm{mg} / \mathrm{l} \mathrm{BAP})$, and $(\mathrm{g}-\mathrm{i})$ browning in the explants.

The medium combinations affected swelling, browning, and infection development in the explants (Tables 2 and 3). Growth and enlargement in the explants in the nutrient media were accepted as swelling. For Ferula orientalis L., the highest swelling ratio 
was observed in the MS7 (100\%) and MS8 (93.8\%) media. For Chaerophyllum macrospermum (Spreng.) Fisch. \& C.A.Mey., maximum swelling was also observed in the same medium combinations (Table 2). For Ferula orientalis L., the browning ratio in the cultured single-node explants varied between $46.9 \%$ and $78.1 \%$, and the infection ratio in the explants varied between $15.6 \%$ and $28.1 \%$. For Chaerophyllum macrospermum (Spreng.) Fisch. \& C.A.Mey., the same parameters varied between $53.1 \%$ and $84.4 \%$ and between $12.5 \%$ and $25.0 \%$, respectively. For both species, shoot formation increased with increasing swelling ratios (Table 2). Table 3 is given the effects of explant type and medium combination on swelling, browning, and infection development in Eremurus spectabilis. In rhizome explants, no swelling was observed in any of the medium combinations, whereas, in leaf explants, $100 \%$ swelling was observed in all medium combinations. However, shoot formation was not obtained in any of the medium combinations for either of the explant types (Table 3).

Table 2. Effect of medium combination on the swelling, browning, and infection of the single-node explants of Ferula orientalis L. and Chaerophyllum macrospermum (Spreng.) Fisch. \& C.A. Mey.

\begin{tabular}{|c|c|c|c|c|c|c|c|c|c|c|c|c|c|c|}
\hline \multirow{3}{*}{ 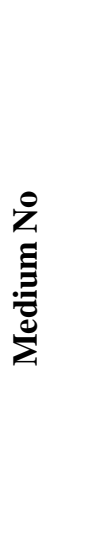 } & & & \multicolumn{6}{|c|}{ Ferula orientalis } & \multicolumn{6}{|c|}{ Chaerophyllum macrospermum } \\
\hline & \multicolumn{2}{|c|}{$\begin{array}{c}\text { Media } \\
\text { composition } \\
(\mathrm{mg} / \mathrm{l})\end{array}$} & \multirow{2}{*}{ 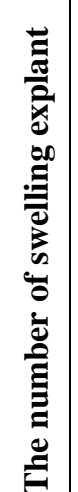 } & \multirow{2}{*}{ 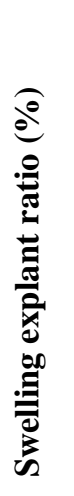 } & \multirow{2}{*}{ 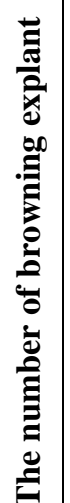 } & \multirow{2}{*}{ 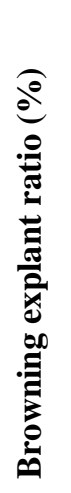 } & \multirow{2}{*}{ 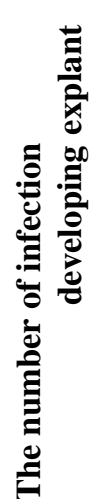 } & \multirow{2}{*}{ 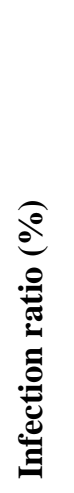 } & \multirow{2}{*}{ 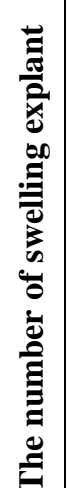 } & \multirow{2}{*}{ 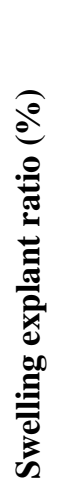 } & \multirow{2}{*}{ 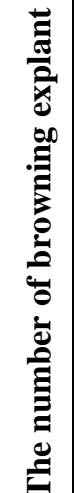 } & \multirow{2}{*}{ 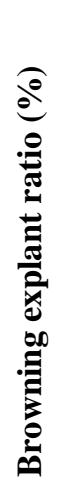 } & \multirow{2}{*}{ 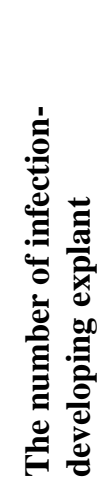 } & \multirow{2}{*}{ 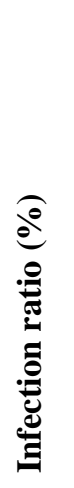 } \\
\hline & $\begin{array}{l}9 \\
\dot{7} \\
i\end{array}$ & 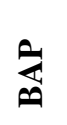 & & & & & & & & & & & & \\
\hline MS1 & 0.5 & - & 12 & 37.5 & 20 & 62.5 & 9 & 28.1 & 13 & 40.6 & 27 & 84.4 & 5 & 15.6 \\
\hline MS2 & 1.0 & - & 19 & 59.4 & 25 & 78.1 & 5 & 15.6 & 10 & 31. & 26 & 81.3 & 6 & 18. \\
\hline MS3 & 2.0 & - & 20 & 62.5 & 25 & 78.1 & 7 & 21.9 & 12 & 37. & 24 & 75.0 & 8 & 25.0 \\
\hline MS4 & 0.5 & 1.0 & 27 & 84 & 18 & 56.3 & 5 & 15.6 & 16 & 50 & 20 & 62.5 & 6 & 18.8 \\
\hline MS5 & 1.0 & 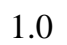 & 20 & 62.5 & 18 & 56.3 & 9 & 28.1 & 16 & 50.0 & 18 & 56.3 & 7 & 21.9 \\
\hline MS6 & 2.0 & 1.0 & 22 & 68.7 & 19 & 59.4 & 6 & 18.8 & 18 & 56.3 & 21 & 65.6 & 5 & 15.6 \\
\hline MS7 & 0.5 & 2.0 & 32 & 100 & 16 & 50.0 & 5 & 15.6 & 27 & 84.4 & 19 & 59.4 & 4 & 12.5 \\
\hline MS8 & 1.0 & 2. & 30 & 93.8 & 15 & 46.9 & 7 & 21.9 & 30 & 93.8 & 17 & 53.1 & 5 & 15.6 \\
\hline MS9 & 2.0 & 2.0 & 21 & 65.6 & 18 & 56.3 & 9 & 28.1 & 14 & 43.8 & 20 & 62.5 & 8 & 25.0 \\
\hline
\end{tabular}

In rhizome explants, browning ratios and infection ratios varied between $50 \%$ and $79.2 \%$ and between $20.8 \%$ and $50 \%$, respectively. In leaf explants, the values varied between $68.8 \%$ and $100 \%$ and between $6.3 \%$ and $31.5 \%$, respectively (Table 3). Browning that occurs under in vitro conditions causes losses in the vitality of tissues in many phenolic compound-rich species. It is known that adding phenol-captivating substances such as polyvinylpyrrolidone (PVP), active carbon (AC), and silver nitrate $\left(\mathrm{AgNO}_{3}\right)$ to nutrient media can prevent tissue browning by captivating polyphenol compounds and thereby slowing their synthesis (Teixeira et al., 2006; Alp et al., 2010). Therefore, we presume that in further studies on the same species, adding these compounds to nutrient media may help reduce losses due to browning. Moreover, there 
are reports on the phytotoxic effects of antibiotics, which are added to nutrient media to prevent infections, and their browning-increasing effect on tissues. In the present study, infection development in explants were observed at varying ratios depending on the species and media composition In further studies on these species, using explants from sterile seedlings that are developed under in vitro conditions will minimize infections.

Table 3. Effect of medium combination and explant types on swelling, browning, and infection development of the rhizome and leaf explants of Eremurus spectabilis M. Bieb.

\begin{tabular}{|c|c|c|c|c|c|c|c|c|c|c|c|c|c|c|}
\hline \multirow[t]{2}{*}{ 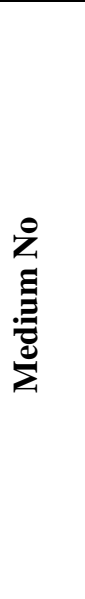 } & \multicolumn{2}{|c|}{$\begin{array}{c}\text { Media } \\
\text { compositon } \\
(\mathrm{mg} / \mathrm{l})\end{array}$} & \multicolumn{2}{|c|}{ 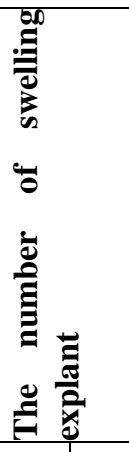 } & \multicolumn{2}{|c|}{ 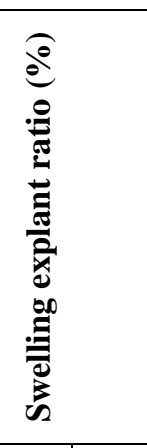 } & \multicolumn{2}{|c|}{ 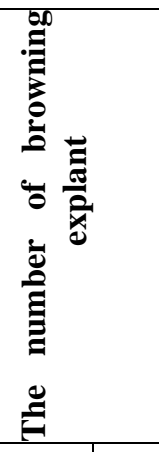 } & \multicolumn{2}{|l|}{ 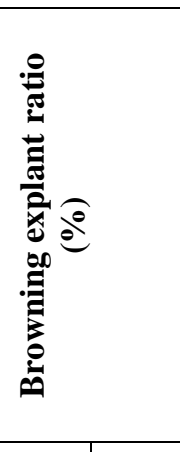 } & \multicolumn{2}{|c|}{ 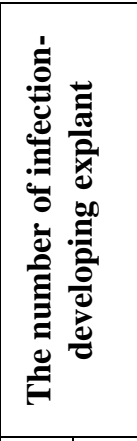 } & \multicolumn{2}{|l|}{ 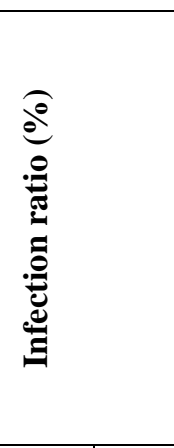 } \\
\hline & $\underset{i}{i}$ & $\stackrel{i}{a}$ & : & ప్త & 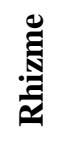 & ఫ్త & 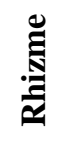 & ప్ & 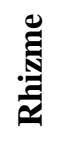 & 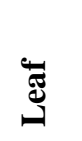 & 节 & $\bar{\Xi}$ & 苞 & ङ્ \\
\hline MS1 & 0.5 & - & - & 16 & - & 100 & 17 & 16 & 70.8 & 100 & 7 & - & 29.2 & - \\
\hline MS2 & 1.0 & - & - & 16 & - & 100 & 19 & 15 & 79.2 & 93.8 & 5 & 1 & 20.8 & 6.3 \\
\hline MS3 & 2.0 & - & - & 16 & - & 100 & 17 & 14 & 70.8 & 87.5 & 7 & 2 & 29.2 & 12.5 \\
\hline MS4 & 0.5 & 1.0 & - & 16 & - & 100 & 18 & 15 & 75.0 & 93.8 & 6 & 1 & 25.0 & 6.3 \\
\hline MS5 & 1.0 & 1.0 & - & 16 & 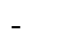 & 100 & 15 & 13 & 62.5 & 81.3 & 9 & 3 & 37.5 & 18.9 \\
\hline MS6 & 2.0 & 1.0 & - & 16 & - & 100 & 14 & 11 & 58.3 & 68.8 & 10 & 5 & 41.7 & 31.5 \\
\hline MS7 & 0.5 & 2.0 & - & 16 & - & 100 & 12 & 11 & 50.0 & 68.8 & 12 & 5 & 50.0 & 31.5 \\
\hline MS8 & 1.0 & 2.0 & - & 16 & . & 100 & 12 & 13 & 50.0 & 81.3 & 12 & 3 & 50.0 & 18.9 \\
\hline MS9 & 2.0 & 2.0 & - & 16 & . & 100 & 13 & 12 & 54.2 & 75.0 & 11 & 4 & 45.8 & 25.0 \\
\hline
\end{tabular}

\section{Conclusions}

This study is the first report of the effects of different explant types and medium combinations on the in vitro regeneration of the medically and aromatically important Ferula orientalis L., Chaerophyllum macrospermum (Spreng.) Fisch. \& C.A.Mey. and Eremurus spectabilis M.Bieb. species. Shoot formations were obtained in the singlenode explants of Ferula orientalis L. and Chaerophyllum macrospermum (Spreng.) Fisch. \& C.A.Mey. at ratios that varied depending on the medium composition. However, shoot formation was not observed for Eremurus spectabilis M.Bieb. in either of the explant types in any of the medium combinations. In further studies, trying different hormones from the auxin-cytokinin group in addition to the combined applications of $2 \mathrm{mg} / \mathrm{l}$ or above doses of BAP and lower auxin $(0.1,0.2$, and $0.5 \mathrm{mg} / \mathrm{l})$ concentrations may prove beneficial for in vitro shoot regeneration in Ferula orientalis L. and Chaerophyllum macrospermum (Spreng.) Fisch. \& C.A.Mey. The results of the present study are expected to contribute to in vitro regeneration studies on these medicinal plants in future. 


\section{REFERENCES}

[1] Alkowni, R., Sawalha K. (2012): Biotechnology for conservation of palestinian medicinal plants. Journal of Agricultural Technology. - 8(4): 1285-1299.

[2] Akowni, R., Solyman, E., Qauod, H.A. (2017): Introducing some of threatened thymus species to in vitro tissue culturing as an approach for their conservation. - Pak. J. Bot., 49(1): 259-264.

[3] Alp, H.A., Duzyaman, E., Ozzaambak, E. (2010): A research on the possibilities of increasing the amount of healthy shoot tips in vitro grown artichoke. - E.U. Faculty of Agriculture Journal. 47(2): 113-122 (in Turkish).

[4] Baksha, R., Jahan, M.A.A., Khatun, R., Munshi, J. L. (2005): Micropropagation of Aloe barbadensis Mill. Through In vitro Culture of Shoot tip Explants. - Plant Tissue Cult. \& Biotech. 15(2): 121-126.

[5] Baytop, T. (1999): Treatment with plants in Turkey; Past and Present. - Nobel Medical Publishing, Istanbul, Turkey (in Turkish).

[6] Block, R., Lankes, C. (1995): Reasons for tissue browning of explants of the apple rootstock M9 during in vitro establishment. - Gartenbauwissenschaft 60: 276-279.

[7] Cakilcioglu, U., Turkoglu, I., Kursat, M. (2007): The ethnobotanical features of Harput (Elazıg) and its vicinity. - Eastern Anatolia Region Research (Daum) Journal 5(2): 22-28 (in Turkish).

[8] Gungor, F. (2002): Investigations on the morphological, biological characteristics and cultivation possibilities of Eremurus spectabilis (BIEB.) FEDTSCH, Prangos ferulacea L. (LINDL.) and Hippomarathum microcarpum (BIEB.) as growing wildly. - (Ph.D. Thesis, unpublished). Ataturk University, Graduate School of Natural and Applied Sciences, Department of Horticultural, Erzurum (in Turkish).

[9] Irvani, N., Solouki, M., Omidi, M., Zare, A.R., Shahnazi, S. (2010): Callus induction and plant regeneration in Dorem ammoniacum D., an endangered medicinal plant. - Plant Cell Tiss Organ Cult 100: 293-299.

[10] Kaplan Ince, O.,Unal, I. (2012): Determination of mineral content and antioxidant activity of Eremurus spectabilis M. Bieb. in Tunceli region. - 6th. National Analytical Chemistry Congress, Hatay, Turkey, pp. 263-263.

[11] Kaval, I. (2011): Etnobotanical features of Geçitli (Hakkari) and surroundings. - (Msc Thesis), Yuzuncu Yil University, Biological Science, 279 pages (in Turkish).

[12] Martin, K.P. (2002): Rapid propagation of Holostemma ada-kodien Schult., a rare medicinal plant, through axillary bud multiplication and indirect organogenesis. - Plant Cell Rep 21: 112-117.

[13] Moncousin, C. (1981): Rapid vegetative propagation of Cynara scyolymus L. II. Impovement of the various techniques. - Hort. Abstract 51: 6926.

[14] Monemi, M.B., Kazemitabar, S.K., Khaniki, G.B., Yasari, E., Sohrevardi, F., Pourbagher, R. (2014): Tissue Culture Study of The Medicinal Plant Leek (Allium ampeloprasum L). - Int J Mol Cell Med 3(2): 118-125.

[15] Murashige, T., Skoog ,F. (1962): A revised medium for rapid growth and bioassays with tobacco tissue cultures. - Physiol Plant 15: 473-497.

[16] Ozcelik, H., (1992): On the herbal cheese from East Anatolia (Turkey). - Journal of Economic Botany, New York Botanical Garden, Bronx, NY 10458.

[17] Ozturk, A., Ozturk, S., Kartal, S. (2000): Properties and uses of herbs participated in Van herb cheese. - Herb Systematic Botanic Journal 7 (2): 167-179 (in Turkish).

[18] Paunescu, A., Hololobiuc, I. (2005): Preliminary researches concerning micropropagation of some endemic plants from Romanian Flora. - Acta Horti Bot.Bucurest. 32: 103-108.

[19] Pourfarzad, A., Najafi, M.B.H., Khodaparast, M.H.H., Khayyat, M.H., Malekpour, A. (2014): Fractionation of Eremurus spectabilis fructans by ethanol: Box-Behnken design and principal component analysis. - Carbohydrate Polymers 106: 374-383. 
[20] Sahrawat, A.K., Chand, S. (2002): Somatic embryogenesis and plant regeneration from root segments of Psoralea corylifolia L., an endangered medicinally important plant. - In Vitro Cell Dev Biol Plant 38: 33-38.

[21] Sharma, R.K. (2015): Callus formation in Ferula jaeschkeana vakte. - International Journal of Plant Sciences 10(1): 98-101.

[22] Skorić, M., Živković, S., Savić, J., Šiler, B., Sabovljević, A., Todorović, S., Grubišić, D. (2012): Efficient one-step tissue culture protocol for propagation of endemic plant, Lilium martagon var. cattaniae Vis. - African Journal of Biotechnology 11(8): 1862-1867.

[23] Tawfik A.A., Noga, G. (2002): Cumin regeneration from seedling derived embryogenic callus in response to amended kinetin. - Plant Cell Tiss Organ Cult 69: 35-40.

[24] Teixeira, S.L., Ribeiro, J.M., Teixeira, M.T. (2006): Influence of $\mathrm{NaClO}$ on nutrient medium sterilization and on pineapple (Ananas comosus cv Smooth cayenne) behavior. Plant Cell, Tissue and Organ Culture 86: 375-378.

[25] Thomas, T.D, Jacob, A. (2004): Direct somatic embryogenesis of Curculigo orchioides Gaertn., an endangered medicinal herb. - J Plant Biotech 6: 193-197.

[26] Thomas, T.D., Maseena, E.A. (2006): Callus induction and plant regeneration in Cardiospermum halicacabum Linn. an important medicinal plant. - Sci Hortic 108: 332336.

[27] Tuzlac1, E. (1985). Vernacular uses of plants in Turkey (I). - J. Pharm. Univ. Mar. 1(1-2): 101-106.

[28] Tuzlacı, E., Doğan, A. (2010): Turkısh Folk Medicinal Plants, IX:Ovacık (Tunceli). Marmara Pharmaceutical Journal 14: 136-143.

[29] Zare, A.R., Solouki, M., Omidi, M., Irvani, N., Mahdi Nezad, N., Rezazadeh S.H. (2010): Callus induction and plant regeneration in Ferula assa foetıda L. (Asafetida), an endangered medicinal plant. - Trakia Journal of Sciences 8(1): 11-18. 